\title{
研究・技術ノート
}

\section{水稲の湛水土中直播栽培における土中出芽性に 優れた系統の選抜・育成}

\author{
太田久稔 $\left.{ }^{*}, 1,2\right)$ ・笹原英樹 ${ }^{1)}$ ・ 小牧有三 ${ }^{1)}$ ・ 上原泰樹 ${ }^{1)}$ ・安東郁男 ${ }^{1)}$ ・ 井辺時雄 ${ }^{1)}$ ・吉田智彦 ${ }^{3)}$ \\ (1) 農業・生物系特定産業技術研究機構・ ${ }^{2)}$ 東京農工大学・ ${ }^{3)}$ 宇都宮大学)
}

\begin{abstract}
要旨：水稲の湛水土中直播栽培において重要な特性である土中出芽性に関し, テープシーダで深度 $2 \mathrm{~cm}$ に播種する戋 場検定，催芽種子を用い， $20^{\circ} \mathrm{C}, 25^{\circ} \mathrm{C}$ ，播種深度 $2,3 \mathrm{~cm}$ の条件での室内検定により，土中出芽性に優れた系統の選 抜を試みた。土中出芽性に優れた遺伝子源として, 赤米 (赤米 No.4, GB 整理番号 00010718 と思われる), Arroz da Terra, Dunghan Shali, Ta Hung Ku を用い，耐倒伏性に優れた良質，良食味品種であるキ又ヒカリ，ぞんとこいとの交配 後代を育成し，上記の土中出芽検定による選抜・育成を行った。赤米， Ta Hung Ku の交配後代では，初期世代から土 中出芽検定による選抜を行い，土中出芽性に優れた系統として，赤米では収 6357, Ta Hung Kuでは，収 6570 (北陸 PL3)，和系 375，和系 376 を選抜できた。一方，Arroz da Terra, Dunghan Shali の交配後代では，葉いもち病が多発する などの問題が多く，土中出芽性に優れた系統を選抜できなかった，そのため，初期世代から土中出芽性の検定を行い 土中出芽性に優れた系統を確実に選抜したり, 雑種集団の規模を大きくし土中出芽性に優れる個体数・系統数を多く するなどの対処が必要と思われた，本試験で選抜した系統は，いずれも収量性と玄米品質に問題があり，今後，優れ た土中出芽性を持つ実用品種の育成においては，品質と収量性を改良することが主な課題になると考えられた．
\end{abstract} キーワード：遺伝子源，検定方法，水稲，直播，テープシーダー，土中出芽.

水稲の直播栽培は生産コストを低下させる有効な方法で ある。しかし直播栽培においては出芽および苗立ちが劣る という問題があり，直播栽培技術の安定化が必要とされて いる. 土中出芽性は出芽抢よび苗立ちを大きく左右する形 質であり，直播栽培の安定化のためには土中出芽性に優れ た直播栽培向け品種の育成を行うことが重要である。しか し土中出芽性の遺伝子源に関する報告がほとんぞなかった ことから，土中出芽性の育種的改良はこれまで添とんと行 われていなかった，著者らは，土中出芽性に関する検定方 法を確立し，すぐれた遺伝子源を見いだした（太田ら 2003b).

そこで, 本研究では, これら土中出芽性に優れた遺伝子 源を用いた交配を行い，その後代から土中出芽性に優れた 系統の選抜・育成を試みた。

\section{材料と方法}

\section{1. 交配母本}

土中出芽性に優れた遺伝子源として, 日本の在来品種で ある赤米 (赤米 No.4, GB 整理番号 00010718 と思われる. 星野ら 1985)，ポルトガル品種である Arroz da Terra (Ogiwara and Terashima 2001)，ハンガリー品種である Dunghan Shali (太田ら 2003b)，中国品種である Ta Hung Ku （太田ら 2003b）を用いた。片親には，強稈で良食味の実用 品種キヌヒカリ，どんとこいを用いた，

\section{2. 土中出芽性の評価方法}

室内検定：土中出芽性の評価方法については，太田ら （2003a）の方法によった。赤米, Arroz da Terra, Dunghan Shali を用いた交配後代については，1品種 20 粒の催芽籾 $\left(25^{\circ} \mathrm{C} 2\right.$ 日間 : 発芽した籾のみ使用) を, バットに充填した 水田土壤に $2 \mathrm{~cm}$ の深度で播種した。播種後は人工気象室 内で湛水状態で $25^{\circ} \mathrm{C}$ 保ち, 20 日後の土中出芽率を調査 した. Ta Hung Kuを用いた交配後代の室内検定においては, 播種深度 $3 \mathrm{~cm}, 20^{\circ} \mathrm{C}$ 条件の場合にどんとこいと Ta Hung $\mathrm{Ku}$ との土中出芽率の差が大きいことから, 播種深度 $3 \mathrm{~cm}$, $20^{\circ} \mathrm{C}$ の条件に変更して検定を行った.

固場検定：太田ら (2003b) の方法より，1品種 100 粒 $\left(25^{\circ} \mathrm{C}, 2\right.$ 日間催芽 $)$ をシーダーマシンで 1 粒ずつ約 2.5 $\mathrm{cm}$ の等間隔に封入したシーダーテープを, 水田用テープ シーダを用いて約 $2 \mathrm{~cm}$ の播種深度で圃場に播種した。播 種は 4 月下旬に行い 30 日後に出芽率を調査した。試験は すべて 2 反復で行った。 室内・國場検定ともに供試種子は 前年と同一条件で栽培, 採種し, 乾燥したのち室温で保存 したものを用いた。

\section{3. 生産力検定試験}

湛水土中直播栽培では苗立ちの良否により収量性が大き く変動することから, 生産力検定試験は, 表面散播湛水直 播栽培で行った。1998 年の施肥は基肥チッ素 $5 \mathrm{~kg} / 10 \mathrm{a}$ ，穂 肥チッ素 $2 \mathrm{~kg} / 10 \mathrm{a}$ の条件で 5 月 2 日に約 $5 \mathrm{~kg} / 10 \mathrm{a}$ を播種し た. 2000 年の施肥は基肥チッ素 $4 \mathrm{~kg} / 10 \mathrm{a}$ ，穂肥チッ素 2 $\mathrm{kg} / 10 \mathrm{a}$ の条件で 4 月 26 日に約 $4 \mathrm{~kg} / 10 \mathrm{a}$ を播種した。 2003 年は緩効性肥料チッ素 $8 \mathrm{~kg} / 10 \mathrm{a}$ を施肥し, 5 月 8 日に約 7 $\mathrm{kg} / 10 \mathrm{a}$ を播種した。試験はすべて 2 反復で行った. 


\section{4. 赤米の交配後代の選抜・育成過程}

1992 年にキヌヒカリ/赤米の交配を行い, 1993 年に戋場 で $\mathrm{F}_{1}$ を養成した。 1994 年, $\mathrm{F}_{2}$ 約 500 個体から立毛選抜し, 以後, 1 系統約 50 個体の系統栽培を行い, 選抜・固定を はかった。1998 年に， $\mathrm{F}_{6}$ 選抜系統を生産力検定試験に供 試した。

\section{Arroz da Terra の交配後代の選抜・育成過程}

1995 年にどんとこい//北陸 148 号（後のどんとこい） /Arroz da Terraの交配を行った。温室で $\mathrm{B}_{1} \mathrm{~F}_{1}$ を 28 個体, $\mathrm{B}_{1} \mathrm{~F}_{2}$ 約 360 個体を養成したのち, 1996 年に苗代放置栽培で, $\mathrm{B}_{1} \mathrm{~F}_{3}$ 約 2000 個体を養成した. 1997 年, $\mathrm{B}_{1} \mathrm{~F}_{4}$ 約 3800 個体 から立毛選抜し, 以後, 1 系統約 50 個体の系統栽培を行い, 選抜・固定をはかった。 2000 年に $\mathrm{B}_{1} \mathrm{~F}_{7}$ 選抜系統を生産力 検定試験に供試した。

\section{Dunghan Shali の交配後代の選抜・育成過程}

1995 年にごんとこい// 北陸 148 号（後のどんとこい） /Dunghan Shali の交配を行った。 1996 年に $\mathrm{B}_{1} \mathrm{~F}_{1}$ を 1 個体戋 場で養成し, 1997 年に $\mathrm{B}_{1} \mathrm{~F}_{2}$ 約 1600 個体, $\mathrm{B}_{1} \mathrm{~F}_{3}$ 約 4000 個 体を国際農林水産業研究セン夕ー沖縄支所で世代促進栽培 した. 1998 年 $\mathrm{B}_{1} \mathrm{~F}_{4}$ 約 3800 個体から立毛選抜し, 以後, 1 系統約 50 個体の系統栽培を行い, 選抜・固定をはかった. 2000 年に $\mathrm{B}_{1} \mathrm{~F}_{6}$ 選抜系統を生産力検定試験に供試した.

\section{Ta Hung Ku の交配後代の選抜・育成過程}

1996 年にどんとこい/Ta Hung Ku の交配を行い, 同年温 室で $F_{1}$ を 27 個体養成した. 1997 年に $F_{2}$ を 579 個体養成し, F3 以後は 1 系統約 50 個体の系統栽培を行い選抜・固定を はかった. 2000 年に $\mathrm{F}_{5}$ 選抜系統を生産力検定試験に供試 した。

また 1997 年にどんとこい// どんとこい/Ta Hung Ku の交 配を行い, 1998 年に $\mathrm{B}_{1} \mathrm{~F}_{1}$ を 96 個体養成した。 $\mathrm{B}_{1} \mathrm{~F}_{2}$ 以後は 1 系統約 50 個体の系統栽培を行い, 選抜・固定をはかった. 2003 年に $\mathrm{B}_{1} \mathrm{~F}_{6}$ 選抜系統を生産力検定試験に供試した.

\section{結果と考察}

\section{1. 日本の在来品種（赤米）を遺伝子源にした場合}

1992 年当時に, 土中出芽性に優れた遺伝子源として考元
られていたものは，赤米などの在来日本稲であった（星野 ら 1985)。そこで, 1992 年に, 倒伏などの点から直播向き と考えられていたキヌヒカリを母本に，星野ら（1985）の報 告に拈いてもっとも有望であった赤米を交配した。赤米は 極長稈で穂発芽しやすく脱粒しやすい特性をもつ(第 1 表). 1994 年に, $\mathrm{F}_{2}$ 約 500 個体から短秙の 10 個体を選抜した. 1995 年の室内検定の結果, 10 系統から土中出芽率 $85 \%$ の 2 系統, 75\%の 2 系統を選抜し, 他に玄米品質が優れてい た 2 系統とあわせて計 6 系統を選抜した。1 1996 年には國 場での選抜で分離が大きい 2 系統群を棄却し，4系統群 8 系統を室内検定に供試した。その結果から, キヌヒカリょ り出芽率が高い 5 系統を選抜した。1997 年に再度圃場検定 を行い, 5 系統群中 3 系統群から固定した 4 系統を選抜し, 収 6357, 収 6358, 収 6359, 収 6360 を付し, 次年度の試験 に供試した。 これらはいずれも, 1995 年の検定において最 も高い出芽率を示した 2 個体に由来していた (第 2 表).

1998 年, 表面散播湛水直播による生産力検定試験に上記 の 4 系統を供試したが，4系統とも，立毛調査において特 に収量が劣ったが, 圃場検定の結果から土中出芽率の高い 収 6357 と収 6358 を選抜した。苗立ち率は, キヌヒカリが $85 \%$, 収 6357 が $93 \%$, 収 6358 が $76 \%$ となり，キヌヒカ リ対比の収量が，68\%，76\%とかなり収量が低いことから， さらに改良を行う必要があると考えられた(第 3 表).

交配開始当時, 初期伸長が重要との考元から, 長程品種 が土中出芽では有利であり, 短秙で優れた土中出芽性をも つ系統を選抜することは難しいと考えていた。しかし，個 体選抜から系統選抜において, 一貫してキヌヒカリ並の秙 長の個体を選抜した結果，2回の土中出芽性の検定におい て, 比較的高い確率で土中出芽率が高い系統を選抜できた。

\section{2. ヨーロッパの遺伝子源 (Arroz da Terra, Dunghan}

\section{Shali）を用いた場合}

遺伝子源の Arroz da Terra, Dunghan Shali は, 極早生で, 短程, 穂発芽しやすく, 脱粒しやすいという特性をもつ(第 1 表).どんとこい// 北陸 148 号/Arroz da Terra の交配後代 $\mathrm{B}_{1} \mathrm{~F}_{4}$ 約 3800 個体から 124 個体, ぞんとこい// 北陸 148 号 /Dunghan Shali の交配後代 $\mathrm{B}_{1} \mathrm{~F}_{4}$ 約 3800 個体から 19 個体を 選抜した. 以後, 主に葉いもち國場抵抗性, 玄米品質, 倒 伏程度による選抜を行い, ぞんとこい//北陸 148 号 /ArroZ

第 1 表 遺伝資源の主な特性 (1997年).

\begin{tabular}{|c|c|c|c|c|c|c|c|c|}
\hline \multirow[t]{2}{*}{ 品種名 } & \multirow{2}{*}{$\begin{array}{l}\text { 出穂期 } \\
\text { (月. 日) }\end{array}$} & \multirow{2}{*}{ 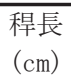 } & \multirow{2}{*}{$\begin{array}{c}\text { 穂長 } \\
(\mathrm{cm})\end{array}$} & \multirow{2}{*}{$\begin{array}{l}\text { 品質 } \\
(1-9)\end{array}$} & \multirow[t]{2}{*}{$\begin{array}{l}\text { 穂発芽 } \\
\end{array}$} & \multirow[t]{2}{*}{ 脱粒 } & \multicolumn{2}{|c|}{ 芒 } \\
\hline & & & & & & & 多少 & 長短 \\
\hline $\begin{array}{l}\text { 赤米 } \\
\end{array}$ & 8.11 & 105 & 23.3 & 赤米 & 極易 & 易 & 中 & 中 \\
\hline Arroz da Terra & 7. 06 & 62 & 18. 4 & 赤米 & 極易 & 易 & 少 & 短 \\
\hline Dunghan Shali & 7. 14 & 78 & 20.8 & 6 & 極易 & 易 & 無 & - \\
\hline Ta Hung Ku & 7.23 & 118 & 18.5 & 8 & 極易 & 易 & 多 & 長 \\
\hline キヌヒカリ & 8.02 & 79 & 18. 8 & 4 & やや易 & 難 & 無 & - \\
\hline どんとこい & 8.04 & 72 & 18.2 & 4 & 中 & 難 & 無 & - \\
\hline
\end{tabular}

玄米品質は, 1 (上上) 9(下下)の9段階, 1996年の結果. 
第 2 表 キヌヒカリ/赤米の交配後代における選抜経過.

\begin{tabular}{|c|c|c|c|c|c|c|c|c|c|c|}
\hline $\begin{array}{c}\text { 1995年 } \\
\text { 系統 } \\
\text { 番号 }\end{array}$ & $\begin{array}{c}\text { F3 } \\
\text { 室内 } \\
\text { 検定 } \\
(\%)\end{array}$ & & $\begin{array}{c}\text { 1996年 } \\
\text { 系統 } \\
\text { 番号 }\end{array}$ & $\begin{array}{c}\mathrm{F} 4 \\
\text { 室内 } \\
\text { 検定 } \\
(\%)\end{array}$ & & $\begin{array}{c}\text { 1997年 } \\
\text { 系統 } \\
\text { 番号 }\end{array}$ & $\begin{array}{c}\text { F5 } \\
\text { 圃場 } \\
\text { 検定 } \\
(\%)\end{array}$ & & $\begin{array}{l}\text { 1998年 } \\
\text { 系統名 }\end{array}$ & $\begin{array}{c}F 6 \\
\text { 固場 } \\
\text { 検定 } \\
(\%)\end{array}$ \\
\hline 1992 & 70 & $x$ & & & & & & & & \\
\hline 1994 & 75 & 選抜 & 分離 & & $\times$ & & & & & \\
\hline 1995 & 63 & $\times$ & & & & & & & & \\
\hline \multirow[t]{2}{*}{1996} & 85 & 選抜 & 1906 & 70 & 選抜 & $5002 \sim 5008$ & $68 \pm 4$ & 選抜 & 収 6357 & $12 \pm 5$ \\
\hline & & & 1908 & 57 & 選抜 & $5009 \sim 5015$ & $57 \pm 7$ & 選抜 & $\begin{array}{l}\text { 収 } 6358 \\
\text { 収 } 6359\end{array}$ & $\begin{array}{c}12 \pm 8 \\
9 \pm 3\end{array}$ \\
\hline \multirow[t]{3}{*}{1997} & 85 & 選抜 & 1910 & 67 & 選抜 & $5017 \sim 5023$ & $62 \pm 7$ & $x$ & & \\
\hline & & & 1912 & 70 & 選抜 & $5024 \sim 5030$ & $60 \pm 10$ & $x$ & & \\
\hline & & & 1913 & 80 & 選抜 & $5032 \sim 5038$ & $72 \pm 7$ & 選抜 & 収6360 & $3 \pm 0$ \\
\hline \multirow[t]{2}{*}{1998} & 75 & 選抜 & 1916 & 37 & $x$ & & & & & \\
\hline & & & 1918 & 17 & $x$ & & & & & \\
\hline 1999 & 63 & $x$ & & & & & & & & \\
\hline 2000 & 53 & $\times$ & & & & & & & & \\
\hline 2001 & 68 & 選抜 & 1925 & 40 & $\times$ & & & & & \\
\hline 2002 & 70 & 選抜 & 分離 & & $x$ & & & & & \\
\hline 赤米 & 80 & & 赤米 & 63 & & 赤米 & $67 \pm 8$ & & 赤米 & - \\
\hline キヌヒカリ & 65 & & キヌヒカリ & 40 & & キヌヒカリ & $55 \pm 7$ & & キヌヒカリ & $3 \pm 2$ \\
\hline
\end{tabular}

1997年の圃場検定は，播種深度約 $1 \mathrm{~cm}$ のデータ，選抜個体の混合種子を供試，平均值士標準誤差.

第 3 表 直播栽培生産力検定試験結果 (1998年，キヌヒカリ/赤米の交配後代).

\begin{tabular}{lccccccccc}
\hline $\begin{array}{c}\text { 系統名 } \\
\text { 品種名 }\end{array}$ & $\begin{array}{c}\text { 苗立ち } \\
\text { 率 } \\
(\%)\end{array}$ & $\begin{array}{c}\text { 出穂期 } \\
(\text { 月. 日 })\end{array}$ & $\begin{array}{c}\text { 秙長 } \\
(\mathrm{cm})\end{array}$ & $\begin{array}{c}\text { 穂長 } \\
(\mathrm{cm})\end{array}$ & $\begin{array}{c}\text { 穂数 } \\
\left(\text { 玄本 } / \mathrm{m}^{2}\right)\end{array}$ & $\begin{array}{c}\text { 米重 } \\
(\mathrm{kg} / \mathrm{a})\end{array}$ & $\begin{array}{c}\text { 標準 } \\
\text { 比率 }\end{array}$ & $\begin{array}{c}\text { 倒伏 } \\
\text { 程度 } \\
(0 \sim 5)\end{array}$ & 脱粒性 \\
\hline 収6357 & 93 & 8.14 & 76 & 19.2 & 502 & 34.9 & 68 & 1.5 & 難 \\
収6358 & 76 & 8.06 & 77 & 16.6 & 550 & 39.4 & 76 & 2.0 & 難 \\
キヌヒカリ & 85 & 8.06 & 76 & 16.1 & 598 & 51.6 & 100 & 3.0 & 難 \\
\hline
\end{tabular}

倒伏程度は, 0 (無) 5 (甚) の6段階.

第 4 表 どんとこい//北陸148号/Arroz da Terra，どんとこい//北陸148号/Dunghan Shali の交配後代における選抜経過.

\begin{tabular}{lcccc}
\hline 組合せ & & 1997年 & 1998年 & 1999年 \\
\hline どんとい//北陸148号/Arroz da Terra & & B1F4 & B1F5 & B1F6 \\
& & 個体選抜 & 系統選抜 & 系統選抜 \\
& 供試数 & 3800 & 124 & 35 \\
& 選抜数 & 124 & 7 & 4 \\
\hline どんとこい//北陸148号/Dunghan Shali & & & B1F4 & B1F5 \\
& & & 個体選抜 & 系統選抜 \\
& 供試数 & & 3800 & 19 \\
& 選抜数 & & 19 & 2 \\
\hline
\end{tabular}

da Terra の交配後代から 4 系統を選抜し, 収 6470 , 収 6471，収 6475，収 6477 を付し，ぞんとこい// 北陸 148 号 /Dunghan Shali の交配後代からは 2 系統を選抜し，収 6559, 収 6620 を付し，次年度の試験に供試した (第 4 表)。

両組合せとも圑場に抒いて葉いもちが多発し, Arroz da Terra, Dunghan Shali は，いもち病に問題がある遺伝子源で あることがわかった，また，玄米品質がかなり劣り，交配 後代における分離も大きく，良質で固定した系統を選抜す るのは困難であった。他にも Arroz da Terra の交配後代は 大粒赤米, Dunghan Shali の交配後代は，短稈でも倒伏しゃ すい個体・系統が多いことが問題であった.
2000 年の戋場検定の結果, いずれの選抜系統もどんとこ いやキヌヒカリと土中出芽率に差がない結果であり，直播 生産力検定では赤米を母本にした後代と同様にすべての選 抜系統が少収であった (第 5 表).

キヌヒカリ/赤米の組合せの場合は， $\mathrm{F}_{2}$ 集団から選抜し た 10 個の短秙個体の中に土中出芽率が高い 2 個体があり, 固定化を進めて出芽性に優れた短稈系統を選抜できた。し かし，どんとこい// 北陸 148 号/Dunghan Shali の組合せの 場合は, $\mathrm{B}_{1} \mathrm{~F}_{1}$ 交配種子数が少ないことから, 土中出芽性に 関する遺伝子を後代に残せなかった。また，どんとこい// 北陸 148 号 /Arroz da Terra, どんとこい//北陸 148 号 
第 5 表 直播栽培生産力検定試験および土中出芽围場検定結果

（2000年，どんとこい//北陸148号/Arroz da Terra，どんとこい//北陸148号/Dunghan Shaliの交配後代).

\begin{tabular}{|c|c|c|c|c|c|c|c|c|c|c|c|}
\hline $\begin{array}{l}\text { 系統名 } \\
\text { 品種名 }\end{array}$ & 遺伝子源 & $\begin{array}{c}\text { 土中 } \\
\text { 出芽率 } \\
(\%)\end{array}$ & $\begin{array}{c}\text { 苗立ち } \\
\text { 率 } \\
(\%) \\
\end{array}$ & $\begin{array}{l}\text { 出穂期 } \\
\text { (月.日) }\end{array}$ & $\begin{array}{l}\text { 秙長 } \\
(\mathrm{cm}) \\
\end{array}$ & $\begin{array}{l}\text { 穂長 } \\
(\mathrm{cm}) \\
\end{array}$ & $\begin{array}{l}\text { 穂数 } \\
\left(\text { 本 } / \mathrm{m}^{2}\right)\end{array}$ & $\begin{array}{l}\text { 玄米重 } \\
(\mathrm{kg} / \mathrm{a})\end{array}$ & $\begin{array}{l}\text { 標準 } \\
\text { 比率 }\end{array}$ & 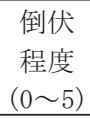 & 脱粒性 \\
\hline 収6471 & Arroz da Terra & $53 \pm 10$ & 53 & 7.28 & 62 & 15.8 & 436 & 52.2 & 90 & 1.0 & 難 \\
\hline 収6475 & Arroz da Terra & $58 \pm 1$ & 50 & 7. 29 & 55 & 16. 7 & 592 & 49.8 & 86 & 2.5 & 難 \\
\hline はえぬき & & $47 \pm 17$ & 54 & 7. 31 & 65 & 17.0 & 558 & 57.8 & 100 & 2.0 & 難 \\
\hline 収6470 & Arroz da Terra & $51 \pm 6$ & 70 & 7.31 & 62 & 17.5 & 480 & 40.6 & 92 & 0.0 & 難 \\
\hline 収6477 & Arroz da Terra & $60 \pm 17$ & 76 & 8. 01 & 58 & 17. 1 & 464 & 39.1 & 89 & 0.0 & 難 \\
\hline キヌヒカリ & & $46 \pm 1$ & 65 & 8. 01 & 63 & 17.0 & 424 & 44.2 & 100 & 0.0 & 難 \\
\hline どんとこい & & $57 \pm 1$ & 75 & 8.02 & 59 & 16.8 & 470 & 55.8 & 126 & 0.0 & 難 \\
\hline 収6569 & Dunghan Shali & $52 \pm 6$ & 78 & 7. 29 & 57 & 17.2 & 506 & 45.3 & 81 & 0.0 & 難 \\
\hline はえぬき & & $47 \pm 17$ & 69 & 7. 29 & 63 & 16.9 & 608 & 56.2 & 100 & 0.0 & 難 \\
\hline 収 6620 & Dunghan Shali & $49 \pm 11$ & 68 & 8.01 & 67 & 15.7 & 646 & 43.9 & 94 & 0.0 & 難 \\
\hline キヌヒカリ & & $46 \pm 1$ & 60 & 8. 04 & 75 & 17.0 & 494 & 46.7 & 100 & 1.0 & 難 \\
\hline どんとこい & & $57 \pm 1$ & 68 & 8.04 & 68 & 17.0 & 552 & 60.8 & 130 & 2.0 & 難 \\
\hline
\end{tabular}

倒伏程度は，0 (無) 〜 (甚) の6段階，土中出芽率は平均值士標準誤差.

第 6 表 どんとこい/Ta Hung Kuの交配後代における選抜経過.

\begin{tabular}{|c|c|c|c|c|c|c|c|}
\hline $\begin{array}{c}\text { 1998年 } \\
\text { 系統 } \\
\text { 番号 }\end{array}$ & $\begin{array}{c}\text { F3 } \\
\text { 糐場 } \\
\text { 検定 } \\
(\%)\end{array}$ & $\begin{array}{c}\text { 1999年 } \\
\text { 系統 } \\
\text { 番号 }\end{array}$ & $\begin{array}{c}\mathrm{F} 4 \\
\text { 畨場 } \\
\text { 検定 } \\
(\%)\end{array}$ & $\begin{array}{c}\mathrm{F} 4 \\
\text { 室内 } \\
\text { 検定 } \\
(\%)\end{array}$ & & $\begin{array}{l}2000 \text { 年 } \\
\text { 系統名 }\end{array}$ & $\begin{array}{c}\mathrm{F} 5 \\
\text { 畨場 } \\
\text { 検定 } \\
(\%) \\
\end{array}$ \\
\hline 7013 & $26 \pm 11$ & $7111 \sim 7115$ & $18 \pm 7$ & $60 \pm 0$ & 選抜 & 収6570 & $72 \pm 5$ \\
\hline 7338 & $30 \pm 16$ & $7172 \sim 7176$ & $13 \pm 4$ & $48 \pm 22$ & $x$ & & \\
\hline 7309 & $31 \pm 20$ & $7166 \sim 7170$ & $9 \pm 4$ & $40 \pm 25$ & $x$ & & \\
\hline 7405 & $34 \pm 21$ & $7188 \sim 7192$ & $8 \pm 3$ & $48 \pm 13$ & $\times$ & & \\
\hline 7203 & $35 \pm 20$ & $7150 \sim 7154$ & $10 \pm 2$ & $50 \pm 12$ & $x$ & & \\
\hline 7163 & $41 \pm 21$ & $7128 \sim 7132$ & $12 \pm 1$ & $40 \pm 15$ & $x$ & & \\
\hline 7187 & $45 \pm 25$ & $7139 \sim 7143$ & $16 \pm 5$ & $40 \pm 15$ & 選抜 & 収6621 & $52 \pm 1$ \\
\hline Ta Hung Ku & $27 \pm 3$ & Ta Hung Ku & $13 \pm 4$ & $63 \pm 7$ & & Ta Hung Ku & $74 \pm 3$ \\
\hline どんとこい & $6 \pm 3$ & どんとこい & $0 \pm 0$ & $13 \pm 3$ & & どんとこい & $57 \pm 1$ \\
\hline
\end{tabular}

1999年の検定は，選抜個体の混合種子を供試，平均值士標準誤差.

/Dunghan Shali の交配後代においては，分離が多く，固場 でいもち病が多発し，倒伏個体が多かったことから，出芽 性に優れた系統を選抜できなかった。そのため，雑種集団 の規模を大きくし土中出芽率の高い個体の数を多くするこ とが必要と考えられた。

\section{3. 新しい遺伝子源である Ta Hung Ku を用いた場合}

Ta Hung Ku は，極早生で長秙，長芒を多数有し，穂発芽 しやすく，脱粒しやすいという劣悪な特性をもつ(第 1 表) が，2003 年の葉いもち病特性検定試験から葉いもち病に強 いという優れた特性をもっている。

ぞんとこい/Ta Hung $\mathrm{Ku}$ の組合せにおいて, 1997 年に $\mathrm{F}_{2}$ 集団 539 個体から, 穂発芽個体, 極晚性個体, 不稔個体, 弱勢で種子量が少ない個体を除いた 371 個体を選抜した. 1998 年に 371 系統 $\left(\mathrm{F}_{3}\right)$ を養成すると同時に, 種子量が少 ない系統を除く 347 系統を戋場検定に供試した。固場検定 で出芽率の高い 33 系統を選抜し，さらにその中から固定 度が高い 7 系統を選抜した. 1999 年に 7 系統群 35 系統 $\left(\mathrm{F}_{4}\right)$ を栽培するとともに戋場検定に供試した。その結果， $\mathrm{F}_{3}$ で
は土中出芽率が高く評価されたものの， $\mathrm{F}_{4}$ では必ずしも高 くない系統があった。 そこで, 2 年間ともに土中出芽率の 高い 2 系統を選抜し, 収 6570 , 収 6621 を付し, 次年度の 試験に供試した (第 6 表).

戋場検定では，播種深度を制御するのが難しく，播種深 度が浅いと出芽率を高く評価する場合がある。本試験の $\mathrm{F}_{3}$ 世代の圃場検定においても, 播種深度が浅くなり出芽率を 高く評価した系統が選抜された可能性が高い.したがって, 今後, Ta Hung Ku 並の高出芽系統を選抜するには，選抜系 統数を多くし複数年の選抜をする必要があると考元られた.

$\mathrm{F}_{5}$ 世代で選抜された 2 系統, 収 6570 と収 6621 の土中出 芽率は, Ta Hung Ku が 74\%, どんとこいが $57 \%$ の時に, それぞれ $72 ， 52 \%$ となった (第 6 表)。また, 収 6621 につ いては, 土中出芽率に関して分離した. 生産力検定の結果 は, 収 6570 は, ぞんとこい並の短秙で, 脱粒は難であっ たが, 芒が多く大粒で品質が不良であり, キヌヒカリ対比 の収量が $87 \%$ と少収であった。収 6621 も収 6570 とほぼ同 様の特性であるが, 品質が収 6570 より優れていた (第 7 表). 収 6570 は, その後も調査が続けられ，2004 年に土中出芽 
第 7 表 直播栽培生産力検定試験結果 (2000年, どんとこい/Ta Hung Kuの交配後代).

\begin{tabular}{ccccccccccc}
\hline $\begin{array}{c}\text { 系統名 } \\
\text { 品種名 }\end{array}$ & $\begin{array}{c}\text { 苗立ち } \\
\text { 率 } \\
(\%)\end{array}$ & $\begin{array}{c}\text { 出穂期 } \\
(\text { 月. 日 })\end{array}$ & $\begin{array}{c}\text { 㷏長 } \\
(\mathrm{cm})\end{array}$ & $\begin{array}{c}\text { 穂長 } \\
(\mathrm{cm})\end{array}$ & $\begin{array}{c}\text { 穂数 } \\
\left(\text { (本 } / \mathrm{m}^{2}\right)\end{array}$ & $\begin{array}{c}\text { 玄米重 } \\
(\mathrm{kg} / \mathrm{a})\end{array}$ & $\begin{array}{c}\text { 標準 } \\
\text { 比率 }\end{array}$ & $\begin{array}{c}\text { 玄米 } \\
\text { 品質 } \\
(1 \sim 9)\end{array}$ & $\begin{array}{c}\text { 倒伏 } \\
\text { 程度 } \\
(0 \sim 5)\end{array}$ & 脱粒性 \\
\hline 収6570 & 69 & 7.30 & 69 & 19.6 & 330 & 42.3 & 79 & 8.0 & 1.0 & 難 \\
はえぬき & 69 & 7.29 & 63 & 16.9 & 608 & 56.2 & 100 & 4.5 & 0.0 & 難 \\
キヌヒカリ & 63 & 8.03 & 69 & 16.7 & 494 & 48.5 & 91 & 5.5 & 0.0 & 難 \\
\hline 収6621 & 63 & 8.01 & 66 & 19.5 & 386 & 42.5 & 91 & 6.0 & 0.0 & 難 \\
キヌヒカリ & 60 & 8.04 & 75 & 17.0 & 494 & 46.7 & 100 & 5.0 & 1.0 & 難 \\
どんとこい & 68 & 8.04 & 68 & 17.0 & 552 & 60.8 & 130 & 4.5 & 2.0 & 難 \\
\hline
\end{tabular}

倒伏程度は0 (無) 〜 (甚)の6段階, 玄米品質は1 (上上) 9 (下下)の9段階.

第 8 表 どんとこい//どんとこい/Ta Hung Kuの交配後代における選抜経過.

\begin{tabular}{|c|c|c|c|c|c|c|c|c|c|c|c|c|}
\hline $\begin{array}{c}\text { 1999年 } \\
\text { 系統 } \\
\text { 番号 }\end{array}$ & $\begin{array}{c}\text { B1F2 } \\
\text { 圃場 } \\
\text { 検定 } \\
(\%) \\
\end{array}$ & $\begin{array}{c}\text { 2000年 } \\
\text { 系統 } \\
\text { 番号 }\end{array}$ & $\begin{array}{c}\text { B1F3 } \\
\text { 畨場 } \\
\text { 検定 } \\
(\%) \\
\end{array}$ & & $\begin{array}{c}\text { 2001年 } \\
\text { 系統 } \\
\text { 番号 }\end{array}$ & $\begin{array}{c}\text { B1F4 } \\
\text { 畨場 } \\
\text { 検定 } \\
(\%) \\
\end{array}$ & $\begin{array}{c}\text { B1F4 } \\
\text { 室内 } \\
\text { 検定 } \\
(\%) \\
\end{array}$ & & $\begin{array}{c}\text { 2002年 } \\
\text { 系統 } \\
\text { 番号 }\end{array}$ & $\begin{array}{c}\text { B1F5 } \\
\text { 室内 } \\
\text { 検定 } \\
(\%)\end{array}$ & $\begin{array}{l}\text { 2003年 } \\
\text { 系統名 }\end{array}$ & $\begin{array}{c}\text { B1F6 } \\
\text { 室内 } \\
\text { 検定 } \\
(\%) \\
\end{array}$ \\
\hline \multirow[t]{2}{*}{7014} & $13 \pm 10$ & 7005 & $72 \pm 2$ & 選抜 & 4036 & $35 \pm 14$ & $40 \pm 13$ & $x$ & & & & \\
\hline & & 7006 & $71 \pm 14$ & 選抜 & 4039 & $45 \pm 9$ & $50 \pm 10$ & 選抜 & 3727 & $20 \pm 10$ & 和系373 & $\begin{array}{r}28 \pm 8 \\
-\end{array}$ \\
\hline \multirow{6}{*}{7070} & -12 & 71 & & $-x$ & & & & & & & & \\
\hline & $13 \pm 3$ & 7100 & $71 \pm 4$ & 選抜 & 4044 & $45 \pm 3$ & $17 \pm 3$ & 選抜 & 3731 & $33 \pm 3$ & 和系 265 & $40 \pm 6$ \\
\hline & & & & & & & & & 3733 & $20 \pm 5$ & 和系374 & $20 \pm 10$ \\
\hline & & & & & 4049 & $47 \pm 9$ & $23 \pm 3$ & $x$ & & & & \\
\hline & & & & & 4050 & $51 \pm 14$ & $17 \pm 10$ & $x$ & & & & \\
\hline & & 7107 & $72 \pm 11$ & - & & & & & & & & \\
\hline \multirow[t]{4}{*}{7072} & $17 \pm 7$ & 7133 & $75 \pm 3$ & $x$ & & & & & & & & \\
\hline & & 7144 & $81 \pm 3$ & 選抜 & 4075 & $59 \pm 6$ & $57 \pm 3$ & 選抜 & 3746 & $85 \pm 5$ & 和系375 & $60 \pm 8$ \\
\hline & & & & & & & & & 3749 & $70 \pm 0$ & 和系376 & $58 \pm 4$ \\
\hline & & 7147 & $74 \pm 2$ & $\times$ & & & & & & & & \\
\hline Ta Hung Ku & $10 \pm 3$ & Ta Hung Ku & $72 \pm 3$ & & Ta Hung Ku & $65 \pm 4$ & $67 \pm 7$ & & Ta Hung Ku & $40 \pm 10$ & Ta Hung Ku & $60 \pm 4$ \\
\hline どんとこい & $1 \pm 1$ & どんとこい & $51 \pm 8$ & & どんとこい & $30 \pm 3$ & $3 \pm 3$ & & どんとこい & $10 \pm 10$ & どんとこい & $13 \pm 9$ \\
\hline
\end{tabular}

平均值土標準誤差.

性に優れる中間母本新配付系統, 北陸 PL3 と命名された. 北陸 PL3 は, 短秙で脱粒難, 強秙で, 転び型倒伏にも強く, いもち病抵抗性が優れている。穂発芽性は中程度で，玄米 品質, 食味は不良である (注: 平成 16 年度北陸研究センター 水稲育成新配付に関する参考成績書)。したがって，玄米 品質, 食味, 芒についてさらに改良する必要がある.

ぞんとこい//どんとこい/Ta Hung Ku の組合せについて は，1998 年に $\mathrm{B}_{1} \mathrm{~F}_{1}$ 個体 96 個体を栽培し，すべての個体を 採種した。1 1999 年に 96 系統 $\left(\mathrm{B}_{1} \mathrm{~F}_{2}\right)$ を栽培, 同時に土中出 芽性の圃場検定に供試した。1999 年は，播種後の低温のた め土中出芽率は全体的に低い結果であったが，その中から Ta Hung Ku より土中出芽率が高かった 4 系統を選抜した. 2000 年に 4 系統群 132 系統を栽培し, 同時に圑場検定に供 試した。 その結果から 7 系統を選抜した。2001 年に 7 系 統群 79 系統を栽培し，6 系統を選抜した。選抜した 6 系 統のうちほぼ固定した 2 系統を和系 264 , 和系 265 と付し, 次年度の試験に供試した。 2002 年に室内検定でどんとこい $10 \%$, Ta Hung Ku が $40 \%$ の時に，和系 264 が 20\%，和系 265 が 33\%であった。このため, 出芽率の低かった和系 264 は棄却した。和系 265 は芒がやや多く少収で品質に問
題はあったが選抜した。他に分離系統群から固定した 4 系 統を選抜し, 和系 373, 和系 374, 和系 375, 和系 376 と付 し, 次年度の試験に供試した。和系 375 , 和系 376 につい ては，2000 年の圃場検定において Ta Hung Kuより出芽率 が高い 1 系統の後代であった (第 8 表)。2003 年に, 和系 265 , 和系 373 , 和系 374 , 和系 375 , 和系 376 を生産力検 定試験に供試した。そのうち和系 375 , 和系 376 は, 芒が ほとんど認められず，脱粒せず，稈長はやや長いが，日本 晴並の耐倒伏性であった。 品質については, 粒厚が薄いた めやや不良であったが，日本晴より良食味であった（第 9 表)。これら 2 系統は, 2000 年の圃場検定において, もっ とも出芽率が高い系統の後代系統であり, 2002 年, 2003 年の室内検定において Ta Hung Ku 並の土中出芽率であっ た。したがって，和系 375 , 和系 376 は, Ta Hung Ku の土 中出芽性を取り込みながら, 脱粒性, 程長 (倒伏), 芒, 品 質, 食味を改良した系統と考元られた。ささらに, いもち病 にも強く, 優れた土中出芽性をもつ系統として有望である. これら 2 系統を選抜し, 引き続き生産力検定試験, 特性検 定試験を行う予定である. 
第 9 表 直播栽培生産力検定試験結果 (2003年, どんとこい//どんとこい/Ta Hung Kuの交配後代).

\begin{tabular}{|c|c|c|c|c|c|c|c|c|c|c|}
\hline $\begin{array}{l}\text { 系統名 } \\
\text { 品種名 }\end{array}$ & $\begin{array}{c}\text { 苗立ち } \\
\text { 率 } \\
(\%)\end{array}$ & 出穂期 & 稈長 & $\begin{array}{l}\text { 穂長 } \\
(\mathrm{cm})\end{array}$ & $\begin{array}{l}\text { 穂数 } \\
\left(\text { 本 } / \mathrm{m}^{2}\right)\end{array}$ & $\begin{array}{l}\text { 玄米重 } \\
(\mathrm{kg} / \mathrm{a})\end{array}$ & $\begin{array}{l}\text { 標準 } \\
\text { 比率 }\end{array}$ & $\begin{array}{c}\text { 玄米 } \\
\text { 品質 } \\
(1 \sim 9)\end{array}$ & $\begin{array}{c}\text { 倒伏 } \\
\text { 程度 } \\
(0 \sim 9)\end{array}$ & $\begin{array}{c}\text { 食味 } \\
\text { (移植) }\end{array}$ \\
\hline 和系265 & 58 & 8.08 & 69 & 17.7 & 392 & 42.7 & 88 & 5.5 & 0.0 & -1.4 \\
\hline 和系 373 & 58 & 8.11 & 70 & 16.1 & 443 & 47. 7 & 98 & 5.5 & 0.0 & - \\
\hline 和系374 & 61 & 8.08 & 66 & 17.2 & 356 & 46. 0 & 94 & 5.5 & 0.0 & - \\
\hline どんとこい & 66 & 8.16 & 64 & 16.8 & 419 & 48.7 & 100 & 4.5 & 0.0 & - \\
\hline 和系375 & 69 & 8.27 & 82 & 19.2 & 445 & 55.5 & 93 & 6.0 & 4. 0 & -0.5 \\
\hline 和系376 & 74 & 8.26 & 80 & 18.9 & 410 & 56.0 & 94 & 6.0 & 5.0 & -1.0 \\
\hline 日本晴 & 66 & 8.24 & 75 & 18.1 & 556 & 59.8 & 100 & 4.0 & 4.0 & -1.7 \\
\hline
\end{tabular}

倒伏程度は 0 (無) 〜 (甚)の6段階，玄米品質は 1 (上上) 9 (下下)の9段階，食味の基準はコシヒカリ．

\section{4. まとめ}

赤米，Arroz da Terra，DunghanShali，Ta Hung Ku を土中 出芽性に優れた遺伝子源として交配母本にし，その後代か ら土中出芽性に優れる系統を選抜してきた。赤米，Ta Hung $\mathrm{Ku}$ の交配後代では， $\mathrm{F}_{3}$ 系統や $\mathrm{B}_{1} \mathrm{~F}_{2}$ 系統から土中出 芽の選抜を行い，赤米の交配後代から収 6357, Ta Hung $\mathrm{Ku}$ の交配後代から収 6570 (北陸 PL3)，和系 375，和系 376 を 土中出芽性に優れた系統として選抜できた。一方，Arroz da Terra，Dunghan Shali の交配後代からは，土中出芽性に 優れた系統は選抜できなかった。これは，雑種集団の規模 が小さいことと, 交配後代において葉いもち病が多発し, 秙が弱い個体が多かったが原因と思われる。そのため，雑 種集団の規模を大きくし，土中出芽率の高い個体の数を多 くすることや，初期世代から土中出芽率の高い個体を選抜 し, 分離後代から葉いもち病に強い系統や強秙の系統を選 抜するなどの対処が必要であると考えられた。

本試験に用いた Ta Hung Ku は，いもち病に強く，その 交配後代から選抜された和系 375 ，和系 376 は，日本晴よ り葉いもち病に強いという結果が得られた。また，和系 375 はコシヒカリ並とはいえないまでも，日本晴よりは食 味が優れていると考えられた，そのため，Ta Hung Ku を交 配親とする組合せの後代から土中出芽性に優れ，いもち病 に強く，良食味である系統を選抜することは可能であり，
さらにその中から実用品種として栽培される品種を育成す ることも可能と考えられた。

しかし，本試験において選抜された土中出芽性に優れた 系統は，いずれも収量性と玄米品質に問題があり，優れた 土中出芽性を持つ実用品種を育成していくためには，本試 験で得られた中間母本系統の品質と収量性を改良すること が主な課題になると考えられた。また，土中出芽率は試験 条件による変動が大きいので，数世代にわたり選抜を繰り 返して確実に土中出芽率が高い系統を残していくことが必 要である。そのため，今後，DNA マーカーなどによる効 率的な選抜方法を検討する予定である。

\section{引用文献}

星野孝文・岡本正弘・篠田治躬 1985. 湛水深播条件下に抢ける稲籵 出芽性の品種間差異. 育雑 35 (別 2) : 312-313.

Ogiwara, H. and K. Terashima 2001. A varietal difference in coleoptile growth is correlated with seedling establishment of direct seeded rice in submerged field under low-temperature conditions. Plant Prod. Sci. $4: 166-172$.

太田久稔 - 井辺時雄 - 吉田智彦 2003a. 水稲の湛水土中直播栽培にお ける出芽性の検定方法と遺伝的変異. 日作紀 $72: 50-55$.

太田久稔 - 上原泰樹 - 井辺時雄 - 吉田智彦 $2003 \mathrm{~b}$. 水稲の湛水土中 直播栽培における土中出芽性の新たな検定方法と土中出芽性の新 たな遺伝資源。日作紀 $72: 295-300$. 
Breeding of Rice for a High Seedling Emergence Rate in Direct Seeding under a Submerged Soil Condition. :Hisatoshi Ohta $^{*}{ }^{1,2)}$, Hideki Sasahara ${ }^{3)}$, Yuzo Komaki ${ }^{3)}$, Yasuki Uehara ${ }^{4)}$, Ikuo Ando ${ }^{1)}$, Tokio Imbe ${ }^{1)}$ and Tomohiko Yoshida ${ }^{5)}\left({ }^{1)}\right.$ National Institute of Crop Science, Tsukuba Ibaragi 305-8518, Japan; ${ }^{2)}$ Tokyo University of Agriculture and Technology; ${ }^{3)}$ National Agricultural Research Center Hokuriku Research Center; ${ }^{4)}$ National Agricultural Research Center for Tohoku Region; ${ }^{5}$ Utsunomiya University)

Abstract: Rice lines with a high seedling emergence rate were screened by sowing the seed 20 or $30 \mathrm{~mm}$ deep from the soil surface at $20^{\circ} \mathrm{C}$ or $25^{\circ} \mathrm{C}$ in a growth chamber, or placing the seeder-tape $20 \mathrm{~mm}$ deep from the soil surface in the field. As the gene sources of a high seedling emergence rate, we used Akamai from Japan, Arroz da Terra from Portugal, Dunghan Shali from Hungary, and Ta Hung Ku from China. However, these varieties had many inferior characters. To breed a practical cultivar with good agronomic characters in addition to a high seedling emergence rate, the Dontokoi or Kinuhikari were crossed with these varieties. From the hybrid progenies of Akamai and those of Ta Hung Ku, the lines with a high seedling emergence rate were selected by repeating the selection from early generations. From the hybrid progenies of Arroz da Terra and the those of Dunghan Shali, any lines with a high seedling emergence rate were not selected due to much trouble such as the frequent occurrence of leaf blast. For selecting the lines with a high seedling emergence rate, selection should be repeated from early generations. However, the lines selected for a high seedling emergence rate had inferior grain yield and quality, and further attempts of selecting the lines with high brown rice yield and good grain appearance are necessary.

Key words: Direct Seeding, Evaluation Method, Gene Source, Rice, Seedling Emergence, Submerged Soil Condition, Tape Seeder. 